\title{
The Impact of Relationship Marketing on Customer Loyalty in Banking Industry, the Case of Commercial Bank Branches in Dessie Town
}

\author{
Fuad Beshir (MBA) \\ Lecturer, Department of Management, Mekdela Amba University, Ethiopia
}

\begin{abstract}
This study is aimed to explore the impact of relationship marketing dimensions (trust, commitment, conflict handling, and empathy) on customer loyalty, by focusing on the commercial Bank of Ethiopia in Dessie town. A theoretical framework was used as a guideline to test the relationships between relationship marketing dimensions and customer loyalty. A quantitative method which is cross-sectional with deductive approach is applied in this study. In order to gather data, a self-administered questionnaire is designed and was randomly given to the customers of commercial Bank of Ethiopia in Dessie town. Semi- structured interview questions are prepared to get information from the organization which is analyzed qualitatively. The finding of the study shows that relationship marketing dimensions have impact on customer loyalty. All the independent variables are positively and directly related to customer loyalty particularly in commercial Bank of Ethiopia in Dessie town and in general in banking industry. The relationship between relationship marketing and customer loyalty is significant. Therefore, banks should make the whole system on work with customers, and also they are expected to invest more on attracting new customers and retaining the existed ones with regard to relationship marketing to increase customer loyalty.
\end{abstract}

Keywords: Relationship Marketing, Trust, Commitment, Conflict Handling, Empathy, and Customer Loyalty.

DOI: $10.7176 / \mathrm{JMCR} / 80-01$

Publication date:July $31^{\text {st }} 2021$

\section{Introduction}

The survival of organizations depends on its customers. Customers are the source of profits to be earned by a profit making organization and the primary reason for being in the operation for not - profit organizations. Worthington \&Horne (1998) conducted research on relationship marketing model and its application and concluded that relationship marketing is being put forward as a new paradigm for marketing and is particularly relevant for the marketing of financial services, with their potential for long term and wide relationships between financial institution and customer. Ferguson\& Hlavinka (2007), their deeper look into relationship marketing reveals that banks are customizing their relationship-building strategies to create value propositions as unique as the institutions and customers they serve. They also indicated that when banks use loyalty programs to bring about trust and build confidence in the brand, the customer relationship will develop organically, and so will profits. It is argued that building enduring customer relationships is the secret to furthering growth and should be an unquestioned axiom by bankers.

Relationship marketing gives a company new opportunities to gain a competitive edge by moving customers up a loyalty hierarchy from new customers to regular purchasers, then to loyal supporters of the firms goods and services, and finally to advocates who not only buy its products but recommend them to others (Smith,2003). By converting indifferent customers into loyal ones, companies generate repeat sales. The cost of maintaining existing customers is far below the cost of finding new ones, and these loyal customers are profitable ones.

Lacey and Morgan (2009) findings suggest that customers with stronger levels of commitment are indeed more willing to contribute as customer advocates. They also pointed out that relationship marketing represents a dramatic change in buyer-seller interactions from the previous transaction-based marketing that focused on a single transaction. A relative handful study of Ndubisi (2006) have specifically examined that relationship marketing such as trust, commitment and conflict handling have a direct effect on customer loyalty. This study shows the impact of relationship marketing including other underpinnings such as empathy on customer loyalty in Ethiopian case, commercial Bank of Ethiopia in Dessie town.

\subsection{Statement of the Problem}

As the competitive environment becomes more turbulent, the most important issue the sellers face is no longer to provide excellent, good quality products or services, but also to keep loyal customers who will contribute long-term profit to organizations. To compete in such swarming and interactive marketplace, marketers are forced to look beyond the traditional 4Ps of marketing strategy.

In the banking industry, offering quality services is very important to create closer relationship with the 
entire customers. Quality of services has the power to create customer satisfaction. On the other hand poor quality of services results in customer dissatisfaction and customer defection by going to other competitors.

Relationship marketing should be directed towards all customers of the bank. Most banks are characterized by having both profitable and unprofitable customers, where the former subsidize the latter. Retaining the profitable customers has become increasingly difficult in a competitive environment where other financial institutions specialize in offering attractive services and prices to this rewarding segment. To make customers loyal, organizations need some mechanisms that could increase customer loyalty in a coordinate and change oriented bases. One of the mechanisms that can give such benefit is relationship marketing. The application of relationship marketing is crucial in these days. Because a fierce competition all over the world and the effect of globalization, being reluctant to accept relationship marketing will cost the organization a big deal of lose in many ways.

So, the main reason that initiated the researcher to conduct this study is that there are little researches which are conducted on this topic independently and in detail before to indicate the impact of relationship marketing on customer loyalty in Ethiopia, specifically in commercial Bank of Ethiopia in Dessie town. The aim of this study is to investigate the relationship marketing dimensions such as trust, commitment, conflict handling, and empathy of the Bank, in order to discover whether these dimensions has had the intended strengthening effect on customer loyalty. Hence this study attempted to answer the following basic research questions.

- Does relationship marketing influence customer's loyalty towards their bank?

- Does trust, commit, conflict handling and empathy influence customers loyalty towards their bank?

- Is there significant relationship between relationship marketing dimensions and customer loyalty?

\subsection{Objective of the study}

\subsubsection{General objective}

The general objective of this study is to explore the impact of relationship marketing on customer loyalty within commercial bank of Ethiopia, by analyzing the relationship of every construct in the theoretical framework.

\subsubsection{Specific objectives}

To determine whether trust, commitment, empathy and conflict handlings influence customers loyalty towards their bank.

\section{Literature review}

\subsection{Relationship marketing}

Relationship marketing emerged in the 1980s as an alternative to the prevailing view of marketing as a series of transactions, because it was recognized that many exchanges, particularly in the service industry, were relational by nature within a banking setting (Berry, 1983). This author viewed relationship marketing as a strategy to attract, maintain and enhance customer relationships. Gummesson (1994) defined relationship marketing as a strategy in which interactions, relationships and networks are managed.

\subsubsection{Trust}

Relationship marketing is built on the foundation of trust, as research demonstrates (Morgan and Hunt, 1994). They define trust as a willingness to rely on an exchange partner in whom one has confidence. Trust ensures that the relational exchange is mutually beneficial, as the good intentions of partners are not in doubt. Customers buying services are specially benefited by the existence and development of trust (Berry, 1983).

\subsubsection{Commitment}

Commitment is another important determinant of the strength of a marketing relationship, and a useful construct for measuring the likelihood of customer loyalty and predicting future purchase frequency (Morgan andHunt, 1994). These authors defined commitment as an enduring desire to maintain a valued relationship. This implies a higher level of obligation to make a relationship succeed and to make it mutually satisfying and beneficial.

\subsubsection{Conflict handling}

In interpersonal communication, conflict occurs when an individual perceives in compatibility between his or her own personal goals, needs, or desires and those of the other party. In dealing with conflict, people use different strategies to accomplish their goals. Dwyer (1987) defined conflict handling as the ability of each supplier to minimize the negative consequences of manifest and potential conflicts. Conflict handling reflects the supplier to avoid any potential conflict, solve that particular conflict before they create problems and the ability to discuss the solution openly when the problem arises.

\subsubsection{Empathy}

According to Ndubisi (2004) Empathy is the capacity to share and understand another's state of mind or emotion. This author also pointed out that the basic idea of empathy should be characterized is that by looking expressions of the people facial or body movement, or by hearing their tone of voice, which will have immediate sense on how they feel. Empathy often characterized as the ability to put one self into another, or in some way experience the outlook or emotions of another being within one self. Empathy has the added value of reducing reliance on 
legal governance, since exchange partners who are governed by the principle of empathy are more likely to treat others in the manner they would like to be treated.

\subsubsection{Customer loyalty}

Customer loyalty is the most important goal of implementing relationship marketing activities. Oliver (1997) defined customer loyalty as a deeply held commitment to re-buy a preferred product/service consistently in the future, thereby causing repetitive same-brand or same brand- set purchasing, despite situational influences and marketing efforts having the potential to cause switching behavior. It is assumed that customers who are behaviorally loyal to a firm display more favorable attitudes towards the firm, in comparison to competitors. Customer satisfaction and loyalty are highly correlated. Customer satisfaction with a bank relationship is a good basis for loyalty (Leverin and Liljander, 2006).

\subsection{Conceptual frame work}

A conceptual framework is a set of broad ideas and principles taken from relevant fields of enquiry and used to structure a subsequent presentation (Kombo and Tromp, 2009). Based on relationship marketing theory there are relational factors such as trust, commitment, conflict handling, and empathy) that influence customer loyalty. The framework as follows;

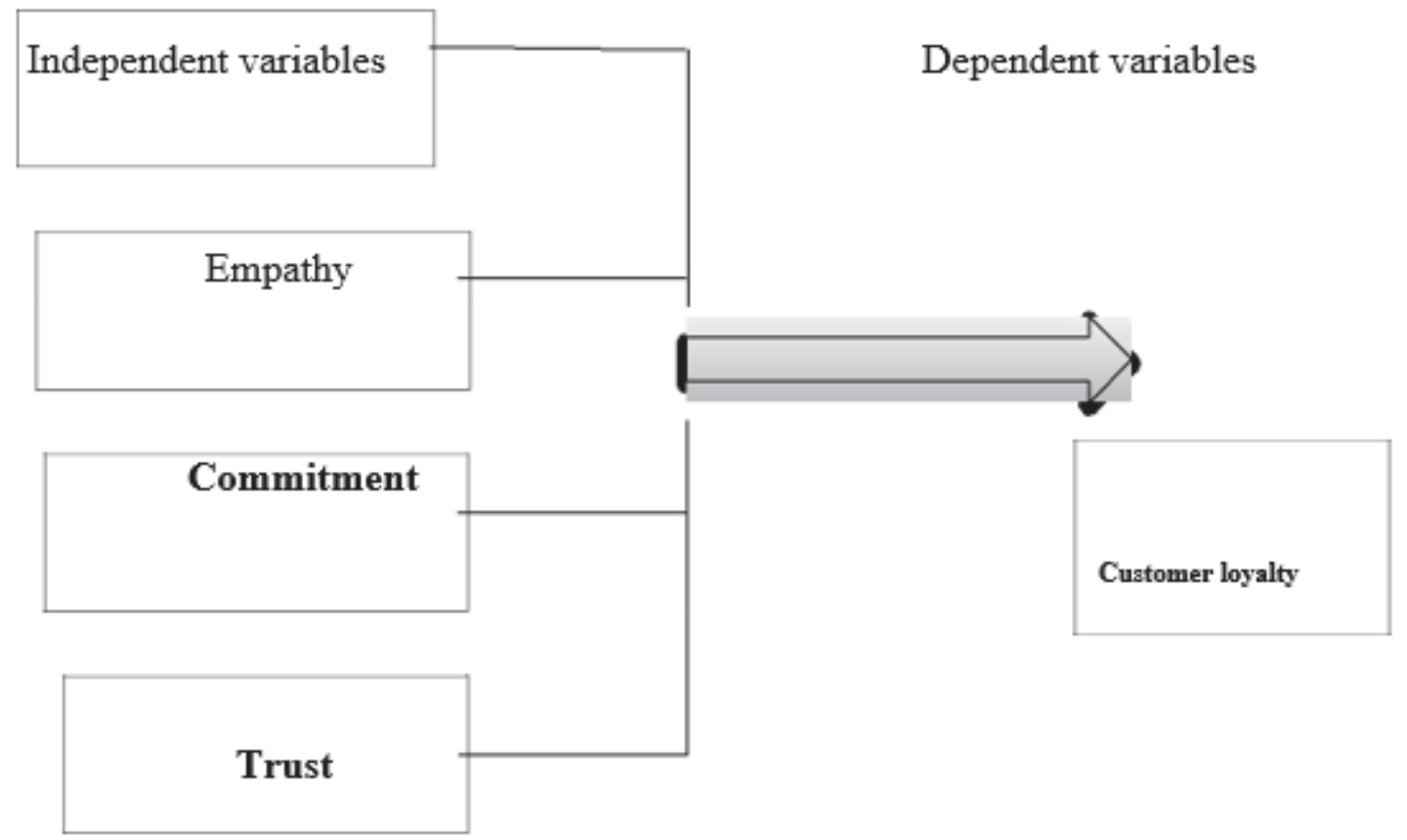

Figure 2.1 Conceptual framework of the study Source, Literature review and Researchers own design (2020)

\section{Research Methodology}

\subsection{Research design}

This study employed more of quantitative case study method to answer the research questions and used some qualitative information to know the current conditions of commercial Bank of Ethiopia with regard to relationship marketing and customer loyalty. In this research a quantitative approach was used which is cross sectional study design with deductive approach by using the customers of the Bank as respondents of the questionnaires.

\subsection{Target population and sample size}

The study was undertaken to examine the impact of relationship marketing on customer loyalty by the customers of commercial bank of Ethiopia in Dessie town. The bank has 15 branches in the city with estimated customer of 145,638 customers; branches are selected by using convenient sampling expecting that the researcher will get the necessary data. To obtain representative samples, simple random sampling technique was used to select customers who were willing to complete the questionnaire. The total numbers of customers listed by the company are 145,638. 10 branches are selected by using simple random sampling technique. In order to answer the research questions of this study a sample of 250 customers were selected randomly from 10 branches to fill the questionnaire. This means that 25 customers were taken from each branch. The 10 branches taken and the 250 customers selected were considered to representative of the target population. This is based on preparatory module which is prepared by Graduate Studies and Research Office. According to this module, in designing a 
study; the researcher chooses the size of effect that is considered important (Abiyet al., 2009).

\subsection{Data collection instruments and variables}

The study used both primary and secondary data as its source of information. Primary data was collected based on structured questionnaire and semi-structured interview. The questionnaire consists of two parts. Part one was prepared to gather general information about the respondents gender, age, education, occupation, monthly income and for how many time the customer using the banks services. Part two was prepared to ask respondents to answer relationship marketing and customer loyalty questions. This part consists of 44 questions and measures the impact of relationship marketing on customer loyalty which is divided in five dimensions. The first dimension, trust consists of 11questionsandwasadoptedfrom Ndubisi\&Wah (2005) and (Dimitriadisetal, 2011). The second dimension which consists 8 questions that measure commitments were adopted from Ndubisi\&Wah (2005) and (Lacey\&Morgan, 2009). The third dimension, empathy, contained five questions which were adopted from Huseyin etal.,(2005). The fourth and fifth dimensions that measure conflict handling and customer loyalty contained 10 questions each adopted from Ndubisi and Wah (2005). Statistical tools regression and correlation models are used for analysis.

\section{Results and discussion}

\subsection{Reliability analysis test}

The result of reliability test for the questionnaire is shown in the following table. As it is indicated in the table, the test result is between 0.86and0.94.Therefore, based on the test, the results for the items are reliable and acceptable.

Table 4.1: Reliability test result for the questionnaire

\begin{tabular}{|l|l|l|}
\hline Item & Number of Item & Cronbachs Alpha \\
\hline Trust & 11 & 0.926 \\
\hline Commitment & 8 & 0.882 \\
\hline Empathy & 5 & 0.865 \\
\hline Customer handling & 10 & 0.918 \\
\hline Customer loyalty & 10 & 0.947 \\
\hline
\end{tabular}

\subsection{Correlation analysis}

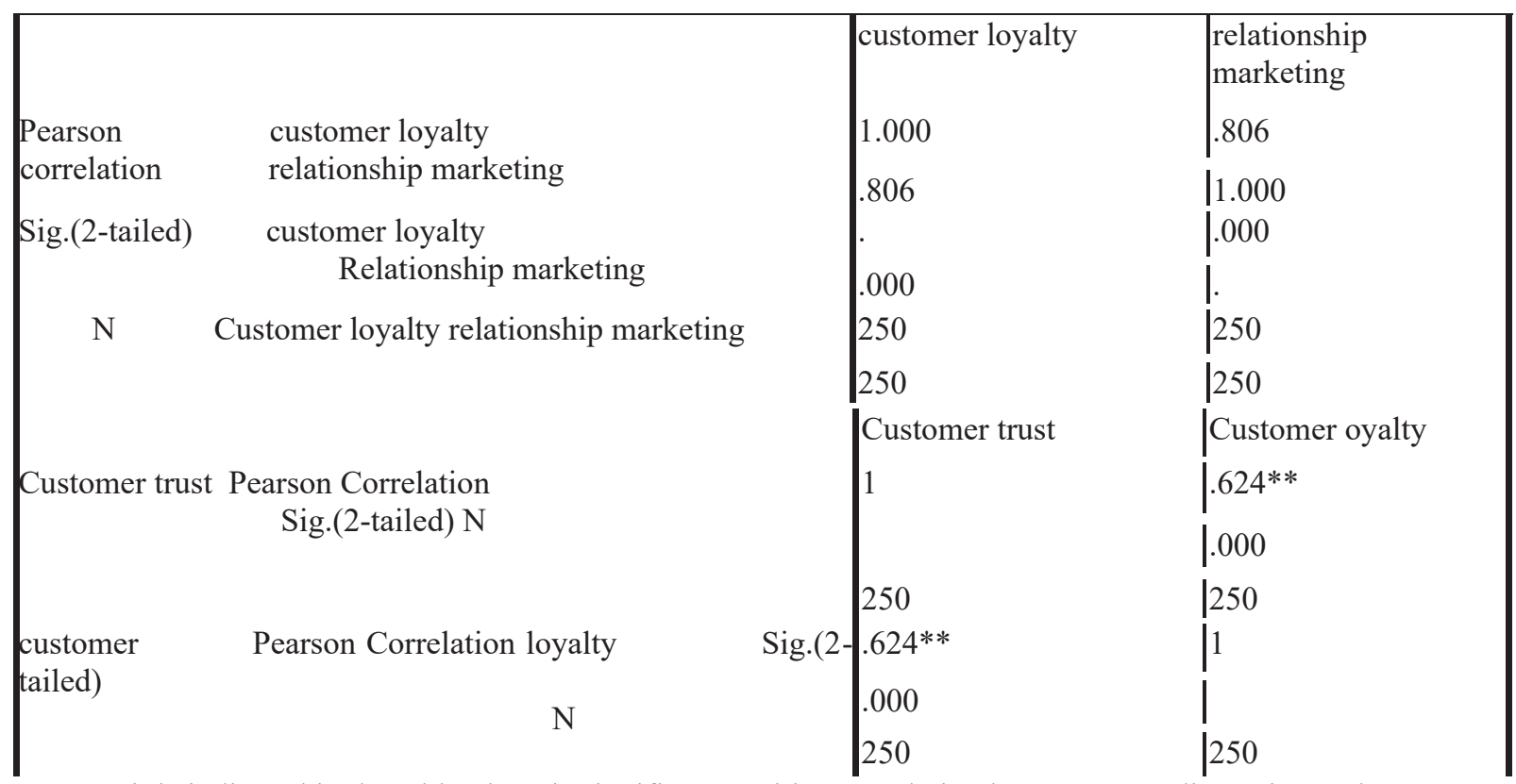

As it is indicated in the table, there is significant positive correlation between trust dimension and customers loyalty. In other words trust dimension and customers loyalty are ccorrelated in a moderate relationship $(\mathrm{r}=0.624)$. The result of correlation analysis prove that empathy, commitment and conflict handling dimension and customers loyalty are correlated with a moderate relationship $(\mathrm{r}=0.581),(\mathrm{r}=0.806)$ and $(\mathrm{r}=0.742)$ respectively.

\subsection{Regression analysis}

Pearson correlation test was conducted to know whether there is significant correlation or not between empathy, 
relationship marketing, trust, commitment, conflict handling and customer's loyalty and the results are shown in.

Table 4.3. Regression analysis result for the five variables

\begin{tabular}{|l|l|l|l|}
\hline Model & $\mathrm{R}$ & $\mathrm{R}^{2}$ & Durbin- watson \\
\hline Model & $\mathrm{R}$ & $\mathrm{R}$ Square & Durbin-Watson \\
\hline Trust $\mathrm{m}$ & .806 & .650 & 1.739 \\
\hline Commit & .624 & .389 & 1.661 \\
\hline $\begin{array}{l}\text { Empathy } \\
\text { Conf han }\end{array}$ & .742 & .649 & 1.924 \\
\hline
\end{tabular}

Table 4.3.1 ANOVA

\begin{tabular}{|l|l|l|}
\hline $\begin{array}{l}\text { Model } \\
\text { Regression } \\
\text { Residual }\end{array}$ & Sig \\
r/ship m & 460.016 & $.000 \mathrm{a}$ \\
trust & 57.914 & \\
commi & 459.256 & \\
empathy & 126.300 & \\
conf hand & 303.619 & \\
& & \\
& & \\
& & \\
\hline
\end{tabular}

Table 4.4 Coefficients of relationship marketing dimensions

\begin{tabular}{|l|l|l|l|l|}
\hline Model & B & Beta & T & Significant \\
\hline Trust & 0.757 & 0.624 & 12.566 & 0.000 \\
\hline Commitment & 0.973 & 0.806 & 21.430 & 0.000 \\
\hline $\begin{array}{l}\text { Conflict } \\
\text { Handling }\end{array}$ & 0.885 & 0.742 & 17.425 & 0.000 \\
\hline Empathy & 0.882 & 0.581 & 11.238 & 0.000 \\
\hline
\end{tabular}

Based on the results, relationship marketing is correlated with customer loyalty. The findings show that relationship marketing activities can explain $65 \%$ of customer's loyalty in banking industry, particularly in commercial Bank of Ethiopia. Relationship marketing elements particularly Commitment and conflict handling have greater impact on customers loyalty and it is more important in shaping that customers prefer about the bank.

Based on the Pearson correlation test of correlation results, trust dimension positively correlated with customer loyalty( $\mathrm{r}=0.624)$.In other words if customers trust the bank, they will be loyal to their banks otherwise they will not be loyal to their banks. The regression analysis of trust dimension and customer loyalty indicates that $38.90 \%$ of the variance R square in customer loyalty has been significantly explained by trust.

Commitment is another element of relationship marketing that is taken in to account to explain customer loyalty. Based on the correlation result as it is shown by Pearson correlation test, commitment dimension is positively and highly correlated with customer loyalty. The correlation coefficient between commitment and customer loyalty is the highest of all correlation results of relationship marketing dimensions which is 0.806 . With regard to the regression analysis of commitment dimension and customers loyalty, $64.9 \%$ of the variance $\mathrm{R}$ square in customers loyalty is significantly explained by commitment.

\section{Conclusion and recommendation}

\subsection{Conclusion}

The main purpose of the study was to examine the impact of relationship marketing on customer loyalty in banking industry, particularly in commercial Bank branches in dessie town. Generally the regression analysis result looks like the following.

- $65 \%$ of customer's loyalty is significantly explained by relationship marketing.

- $\quad 38.9 \%$ of customer's loyalty is significantly explained by trust.

- $64.9 \%$ of customer's loyalty is significantly explained by commitment.

- $33.7 \%$ of customer's loyalty is significantly explained by empathy.

- $\quad 55 \%$ of customer's loyalty is significantly explained by conflict handling.

\subsection{Recommendations}

In light of the findings and conclusions made above, the following possible recommendations are suggested as being valuable to the Bank.

- The Bank must develop customer relationship program that will help them build and support positive customer relationships. Since the bank is providing services to customers, it is a must to give high value for good relationship. Relationship with customers can be improved by explaining to employees, especially in the front line and knowing how much each customer is worth to the business. The more 
employees work together to keep existing customers satisfied, the lesser customer attrition will be.

- To retain and develop loyal customers, the bank should be trust worthy and show commitment, providing individualized attention to customers and must resolve conflicts in a manner that will eliminate unimportant loss and inconvenience to their customers. In Ethiopia, the growing number of banks led to the increase in the competition of banking industry. Therefore, the bank must be well aware of the want and needs of the customers. Nowadays customers are demanding more not only based on the service but they demand the way they are treated. Once they are satisfied with the services that were provided by the banks, they will communicate about the bank or services to the other customers.

- The Bank should put more effort to attract more customers especially in dimensions related to commitment, conflict handling, trust and empathy. In order to create and maintain loyalty, the bank must recognize that many of the core product attributes are necessary, but not sufficient for loyalty. On the other hand, it is a must to have a strong connection with its customers in order to create and maintain customer loyalty. By having strong relationship with customers it is possible to keep customer from switching to other

- Marketers should put their efforts in to implementing relationship marketing in an effective way, in order to enhance customer perceived trust, commitment, conflict handling and empathy.

\section{Reference}

Abiyot, T. (2016).Service quality, Customer Satisfaction and Loyalty of Commercial Banks in Ethiopia.International Journal of Innovation and Scientific Research, Vol. 28 No. 1, pp. 51-65.

Ayenew, N. (2014). Improving customer satisfaction and quality in the banking industry CBE SAAD district management trainee program.

Baumann, C. (2007). Predication of Attitude and Behavioral Intentions in Retail Banking, International Journal Bank. Mark. 25(2): $102-11$.

Berhane, W.(2015).The effect of Service Quality on customer satisfaction(Case study of Lodge sector in Tigray, Ethiopia),Unpublished paper Master's thesis, Mekele University.

Berry, L.( 1987). 'Big ideas in services marketing, Int.Journal of Services Marketing (1): pp.5-.9. Bethelem, T. (2015). The impact of service quality on customer satisfaction (the case of commercial bank of Ethiopia). Master's Thesis, Addis Ababa University.

Dwyer, F.R., (1987).Developing buyer-seller relationships. Journal of Marketing,Vol.51, No.2,pp.11-27.

Evans, K.R. and Beltramini, R.F. (1987). A theoretical model of consumer negotiated pricing:an orientation perspective. Journal of marketing,Vol.51,pp.58-

Gordon Fullerton. (2003). When does commitment lead to loyalty? Journal of service research,Vol.5,No.4,pp.333-344.

Gronroos,C. (1994).From marketing mix to relationship marketing: towards a paradigm shift in marketing. Management Decision,Vol.32,No.2,pp.4-20.

Ndubisi, N. O. and Wah, C.K. (2005). Factorial and discriminant analysis of the underpinnings of relationship marketing and customer satisfaction. International Journal of Bank Marketing,vol.23,No.7,pp.542-557.

Philip Kotler. (1994). Marketing Management: Analysis, Planning, Implementation, and control.8thEd. PrenticeHall, Inc.

Yekunoamlak H. (2004).Thesis on the impact of customer service on customer satisfaction And loyalty in Ethiopia, Addis Ababa University. 